\title{
Speaking Anxiety, English Proficiency, Affective and Social Language Learning Strategies of ESL Engineering Students in a State University in Northern Luzon, Philippines
}

\author{
John N. Cabansag ${ }^{1}$ \\ ${ }^{1}$ College of Arts and Sciences, Isabela State University, Echague, Isabela, Philippines \\ Correspondence: John N. Cabansag, College of Arts and Sciences, Isabela State University, Echague, Isabela, \\ Philippines. E-mail: johncabansag@ymail.com
}

Received: November 16, 2019 Accepted: December 20, 2019 Online Published: January 6, 2020

doi:10.5539/ijel.v10n1p372 URL: https://doi.org/10.5539/ijel.v10n1p372

\begin{abstract}
The primary aim of this paper is to examine the speaking anxiety, affective and social language learning strategies and English language proficiency among ESL Agricultural and Biosystems and Civil Engineering students of a state university in Northern Luzon, Philippines including the possible relationship among the aforementioned variables. The research adapted six (6) items on Affective Language Learning Strategies (ALLS) and six (6) items on Social Language Learning Strategies (SLLS) by Oxford (1990); the Foreign Language Communication Anxiety Scale designed by Horwitz et al. (1986) and the English Proficiency Test developed by Commission on Higher Education were utilized in this study. The findings disclose that the speaking anxiety level of the respondents is moderate. It was noted that they are uneasy every time teachers called them to recite in English class unprepared. To add more, their ALLS and SLLS are both somewhat true for them and the repondents' English Proficiency Level is moderate. It also showed that small negative correlation exists between their English proficiency and speaking anxiety. However, a medium and small positive correlation established when their speaking anxiety and ALLS was correlated. And a small positive correlation was obtained in the correlation between the respondents' speaking anxiety and SLLS. The research concludes with a list of recommendations on how to lessen speaking anxiety in the English language classroom to ESL learners.
\end{abstract}

Keywords: speaking anxiety, English proficiency, affective and social language learning strategies, ESL

\section{Introduction}

The education sector, over the past decades, has witnessed a constant but meaningful twist in the system, resulting in less emphasis on teachers and teaching and heavier concern towards learners and learning. This new educational landscape has been integrated in various ways in language teaching and applied linguistics which highlighted monumental accomplishments on "student-centered curriculum" (Nunan, 1988, 1995) and "authentic learning" (Tudor, 1996). Thus, it is important to focus on the use of language learning strategies (LLS) in second language (L2) learning.

Weinstein and Mayer (1986) in their helpful survey article defined learning strategies (LS) broadly as "the processes and actions employed by learners in acquiring language" needed to help learners in the process of understanding concepts". From this definition, it is clear that educational literature reflects the roots of LS in cognitive science. Furthermore, LS has a significant part in all facets of teaching-learning process, notwithstanding content and context both in classroom settings and more informal learning environments.

Additionally, it is equally significant to determine the relationship of speaking anxiety, English proficiency and the use of affective and social language learning strategies of students. Undoubtedly, ESL students experience different levels of anxiety whenever they are engaged in classroom discussions and other related class activities. This is just but natural among students regardless if they are competent or not. Language anxiety which is a psychological phenomenon affects everyone considering that language learning is a unique process (Horwitz, Horwitz, \& Cope, 1986, p. 128). Anxiety per se is not negative because a certain percentage of anxiety can actually motivate people in learning and acquiring a language. But then teachers and researchers found out that anxiety greatly affects many students in participating class discussion. It hampers individual to engage in communication. Based on Brown (1993), "anxiety is akin to affective state of being uneasy, frustrated, doubtful, 
apprehensive and disturbed. It is described as stressful emotion of being apprehensive especially in learning a second language which includes the macro skills of speaking, listening and learning" (MacIntyre \& Gardner, 1994; as quoted in Subaş1, 2010, p. 30). Its effects could either be positive or negative depending on how the learner perceives it in the acquisition of second language. It is anxiety of this extreme that no doubt hinders students' performance.

Based on the above arguments and premises, researchers in English language teaching were enticed to investigate the causes of anxious students in second language learning in the classrooms via quantitative studies (Bailey, 1983; Hilleson, 1996; Jackson, 2002; Price, 1991; Tsui, 1996). Their findings disclosed that low English proficiency, lack of practice, competition, and complexity of tasks contributed to an anxious student in learning a language.

\subsection{Research Questions}

The study aimed to determine the relationship of speaking anxiety to the English proficiency, affective and social language learning strategies among the ESL agricultural and biosystems and civil engineering students of a state university in Northern Luzon, Philippines.

Specifically, it sought to answer the following questions:

1) What is the speaking anxiety level of the students in different degree programs?

2) What are the affective and social language learning strategies used by the students in different degree programs?

3) What is the English proficiency level of the students when grouped according to degree programs?

4) What relationship exists between speaking anxiety and the selected variables when students are grouped according to degree programs?

\subsection{Significance of the Study}

This study was designed to investigate the relationship of speaking anxiety to the English proficiency, affective and social language learning strategies among the ESL engineering students of a state university in Northern Luzon, Philippines. From the previous literature review, we may observe that learning strategy use, especially the relationship between them, is essential to the knowledge of educators as well as students themselves. Efficient utilization of the language learning strategies may facilitate ESL learners' learning and then consequently improve their language performance.

However, studies focusing on the correlation among affective and social learning strategies, speaking anxiety and English proficiency are surprisingly limited, particularly in science and engineering-related context. The findings of this study may be useful for English teachers to better understand learning strategies of undergraduate learners. To be specific, it could help ESL educators be aware of language learning strategies of ESL students and better understand the relationship between the use of affective and social language learning strategies.

The main findings of this study may also assist in reorienting ESL teachers to be more cognizant of the learning strategies that students use. By having knowledge of such, they may further develop students' language learning competence by training them to use appropriate strategies. More importantly, the main findings on the relationship of the engineering students' language learning strategy use may reveal some inner connections between their cognition and behavior which consequently leads to predilection of teachers towards discovering more appropriate pedagogical approaches in making instructional materials, curriculum, and deploying learning activities.

Recently, a great number of researchers ventured on language anxiety because of the perceived impact on L2 learning, proficiency in English and achievement. This study would be very beneficial to faculty and students as it will contribute body of knowledge in combating anxiety.

\section{Literature Review}

It is a truism that researchers over the past decades developed an interest in the field of language learning strategies employed by ESL learners in the past decades.(Lee \& Oxford, n.d.; Michael, 1997; Park, 2010; Querol, 2010; Shu-chin Yen \& Tun-Whei, 2009) and other researchers have ventured on this field up to the present (Dreyer \& Oxford, 1996; Harris, 2003; Park, 1997; Wharton, 2000 as cited in Radwan, 2010) that yielded to conclusive results that shows successful learners utilize varieties of language learning strategies compared to less successful learners. 
According to Chamot (2004), utilization of language learning strategies drive learners to achieve learning goals. Park (2010) conducted a study on the use of effective and less effective language learning strategies among 164 college students enrolled in English in Korea. He found out that both effective and less effective learners generally used listening strategies as an aid in listening comprehension and show similarities and differences in strategy use. In the search of an effective language learner, Wong and Nunan (2011) carried out a comparative investigation of effective and ineffective learning styles of language learners. The respondents of the study were 110 undergraduate university students in Hong Kong. The respondents were classified either as more effective or less effective learners. Their study concluded that the dominant style of effective language learner is predominantly communicative followed by analytical then lastly authority-oriented. On the other hand, the less effective language learners are split into two: authority-oriented and communicative. But in this case, it should be noted that the authority-oriented are edging out the communicative ones.

Similar to the study of Querol (2010), Kavasoglu (2009) determined the language strategies of 167 pre-service teachers at a university in Turkey. The researcher also used the Strategy Inventory for language Learning of Oxford (2009). Based on the results, metacognitive strategies garnered the highest frequency suggesting that "the most important strategies for effective language learning are metacognitive strategies" as this coordinates the learning process: planning, monitoring, and evaluating.

Radwan (2010) conducted an investigation on the use of language learning strategies by 128 students specializing in English at Sultan Qaboos University (SQU) in Oman. The study sought to find out the relationship among the use of language learning strategies (LLS), gender, and English Proficiency using Oxford's (1990) Strategy Inventory for Language Learners (SILL). The results show that more proficient learners utilized more cognitive, metacognitive, and affective strategies than less proficient learners. It was also found out in the study that EFL cultural setting may be a factor that tells the preferred type of strategies of the learners.

In the Philippine context, Querol (2010) conducted a study on language learning strategies similar to Kavasoglu (2009). Both of the mentioned researchers made use of the SILL of Oxford (1990). The goal of the study of Querol (2010) was to determine and identify both affective language learning strategies (ALLS) and social language learning strategies (SLLS) of 24 junior college students specifically those enrolled in the teaching of literature course from a private university. The participants of the study were four males and 20 females. Furthermore, the two taxonomies of language learning strategies, ALLS and SLLS, were correlated to determine the relationship between the two.

In view of the fact that the SILL of Oxford (1990) is highly comprehensive and wide-ranging, it was used in the studies of Kavasoglu (2009) and Querol (2010). Since the research of Querol (2010) is one of the latest which utilized the Strategy Inventory for language Learning of Oxford (1990), the current study was patterned after such. The researcher's study focused on deriving the strategies that the respondents used frequently and otherwise. After obtaining data, the frequently occurring affective and social language learning strategy were tallied and statistically treated with Pearson correlation. In this regard, similar courses of action were applied to the current study.

\subsection{Communication Anxiety Factors}

MacIntyre and Gardner (1989) did a survey that looked into the three types of language anxiety: communication apprehension, test-anxiety and fear of negative evaluation - manifested that communication anxiety consists of fear of negative evaluation as well. The same authors in 1991 disclosed as communication apprehension maybe experienced by learners outside the classrooms, other types of anxiety may also be felt inside the classroom such as fear of being evaluated and psychological disturbances of looking foolish in front of peers or social anxiety.

Young (1991) revealed that more than sixty-eight percent of her respondents felt relaxed when they were not called to deliver speech in front of the class. Tunaboylu (1993) reported some reasons why students preferred to be silent listeners instead of actively participating in English classes. The study revealed that psychological pressure of committing mistakes in the class and poor vocabulary are the main reasons why learners are anxious. The same findings prevailed in the study of Liu (2007) in China.

Wan et al. (2010) carried out an investigation on the preferred English language activities of students as well as those they thought of as helpful. The results reveal that the students have a comparatively high level of communication apprehension. The study also disclose that the students prefer group discussion as a way of reducing their communicative anxiety.

Wang (2010) conducted the speaking anxiety of Chinese EFL learners as well as the relationships of speaking 
anxiety with other variables, including trait anxiety, unwillingness to communicate, language achievement, speaking self-efficacy, language class risk-taking, and language class sociability. The study indicated that majority of the learners experienced moderate or high level of speaking anxiety. Among all the variables involved in the study, personality factors were found to be the primary causes of speaking anxiety.

\section{Methods}

\subsection{Research Design}

The study used the descriptive-correlational method to determine the relationship of speaking anxiety to the English proficiency, affective and social language learning strategies among the agricultural and biosystems and civil engineering students. A questionnaire was used as the main instrument for gathering data.

\subsection{Respondents of the Study}

This research was conducted in a state university in Northern Luzon, Philippines. A sample size of 257 agricultural and biosystems and civil engineering college students served as the respondents of the study.

Table 1. Distribution of the respondents

\begin{tabular}{ll}
\hline Degree/Program \& Year & Number of Students \\
\hline BSABE 1 & 50 \\
BSABE 2 & 22 \\
BSABE 3 & 15 \\
BSABE 4 & 12 \\
BSABE 5 & 15 \\
BSCE 1 & 39 \\
BSCE 2 & 30 \\
BSCE 3 & 29 \\
BSCE 4 & 21 \\
BSCE 5 & 23 \\
TOTAL & $\mathbf{2 5 7}$ \\
\hline
\end{tabular}

\subsection{Research Instrument Used}

The following research instruments were utilized to gather data for the study: the Strategy Inventory for Language Learners (SILL) adapted from Oxford (1990) for the students' use of strategies in learning English, the Communication Anxiety Factors and Foreign Language Classroom Anxiety Scale (FLCAS) developed by Horwitz et al. (1986) was used to describe the speaking anxiety of the students and English Proficiency Test developed by the Commission on Higher Education, Philippines. It was used to assess the proficiency of the students regarding stress and intonation, verbal ability, reading comprehension, correct usage, identifying errors, spelling and punctuation, and logical organization. There were six proficiency indices used to generate the performance rating in the English Language. These were associated with a specified range from 0 to 100 www.doe.mass.com. The proficiency level were interpreted in the table as follows:

Table 2. English proficiency indices

\begin{tabular}{llll}
\hline Code & Score Range & Proficiency Index Range & Proficiency Level \\
\hline 6 & $5.5-6.00$ & $90.0-100$ & Very High \\
5 & $4.5-5.49$ & $80.0-89.9$ & High \\
4 & $3.5-4.49$ & $70.0-79.9$ & Moderate \\
3 & $2.5-3.49$ & $60.0-69.9$ & Low \\
2 & $1.5-2.49$ & $40.0-59.9$ & Very Low \\
$\mathbf{1}$ & $\mathbf{0 . 0 0 - 1 . 4 9}$ & $\mathbf{0 . 0 - 3 9 . 9}$ & Critically Low \\
\hline
\end{tabular}

\subsection{Data Analysis Techniques}

After the required data were collected, the scores were assessed by means of Statistical Package for Social Sciences (SPSS). The descriptive and inferential statistics were applied to seek the answers to the research questions. Regarding the first research question, mean was conducted to seek the respondents' level of anxiety. The second research question was addressed by using mean and standard deviation in order to determine the affective and social language learning strategies used by the students in different courses. Concerning the third 
research question, mean and standard deviation were performed to find out the English proficiency level of the students when grouped according to degree programs. As regards the fourth research question, Pearson $r$ was used to describe any significant relationship between affective and social language learning strategies, English Language Proficiency and speaking anxiety of the students.

\section{Results}

\subsection{What Is the Speaking Anxiety Level of the Students in Different Degree Programs?}

Table 3. Mean and description of the respondents' anxiety level of BSABE and BSCE

\begin{tabular}{|c|c|c|c|c|}
\hline Activity and Situation & Mean & Anxiety Level (BSABE) & Mean & Anxiety Level (BSCE) \\
\hline 1. I dislike participating in the English class. & 2.11 & moderate & 2.32 & moderate \\
\hline $\begin{array}{l}\text { 2. I feel tense and nervous while participating in the English } \\
\text { class. }\end{array}$ & 2.52 & moderate & 2.82 & moderate \\
\hline 3. I feel afraid to express my opinion in front of my classmates. & 2.84 & moderate & 3.07 & moderate \\
\hline $\begin{array}{l}\text { 4. While speaking English, I get so nervous; I forget things I } \\
\text { really know. }\end{array}$ & 3 & moderate & 3.17 & moderate \\
\hline $\begin{array}{l}\text { 5. I feel frightened when the teacher asks me to answer } \\
\text { questions in the English class. }\end{array}$ & 2.9 & moderate & 2.9 & moderate \\
\hline $\begin{array}{l}\text { 6. I never feel quite sure of myself when I am speaking in the } \\
\text { English class. }\end{array}$ & 2.82 & moderate & 2.93 & moderate \\
\hline $\begin{array}{l}\text { 7. I feel afraid when I don't understand what the teacher is } \\
\text { saying in the English class. }\end{array}$ & 2.75 & moderate & 2.87 & moderate \\
\hline $\begin{array}{l}\text { 8. I feel nervous when I have to speak in the English class } \\
\text { without preparing. }\end{array}$ & 3.21 & moderate & 3.16 & moderate \\
\hline $\begin{array}{l}\text { 9. I get depressed when the teacher corrects my answers in the } \\
\text { English class. }\end{array}$ & 2.46 & moderate & 2.44 & moderate \\
\hline $\begin{array}{l}\text { 10. I feel more tense and nervous in the English class more than } \\
\text { in other classes. }\end{array}$ & 2.55 & moderate & 2.63 & moderate \\
\hline 11. I feel shy when I speak English in front of the class. & 2.83 & moderate & 2.85 & moderate \\
\hline 12. I feel confused by rules I have to learn to speak English. & 2.82 & moderate & 2.75 & moderate \\
\hline $\begin{array}{l}\text { 13. My heart beats faster when the teacher asks me to answer in } \\
\text { the English class. }\end{array}$ & 2.87 & moderate & 2.92 & moderate \\
\hline $\begin{array}{l}\text { 14. I feel afraid that the other students will laugh at me when I } \\
\text { speak in the English class. }\end{array}$ & 2.78 & moderate & 2.96 & moderate \\
\hline $\begin{array}{l}\text { 15. I tremble when I know that I'm going to be called on in the } \\
\text { English class. }\end{array}$ & 2.71 & moderate & 2.8 & moderate \\
\hline $\begin{array}{l}\text { 16. Even if I know the answer; I can't express myself in the } \\
\text { English class. }\end{array}$ & 2.93 & moderate & 2.94 & moderate \\
\hline 17. I often feel like not to attend the English class. & 2.04 & moderate & 1.99 & moderate \\
\hline Average & 2.71 & moderate & 2.80 & moderate \\
\hline
\end{tabular}

The results show that the BSABE and BSCE students' responses in all items of Communication Anxiety Domain are moderate with a mean of 2.71 (BSABE) and 2.80 (BSCE). It is obvious that the responses are positive. They are all moderate. 


\subsection{What Are the Affective and Social Languages Learning Strategies Used by the Students in Different Courses?}

Table 4A. Mean, standard deviation and description of the respondents' ALLS and SLLS

\begin{tabular}{|c|c|c|c|}
\hline $\begin{array}{l}\text { BSABE } \\
\text { Language Learning Strategies }\end{array}$ & Mean & $\begin{array}{l}\text { Std. } \\
\text { Deviation }\end{array}$ & $\begin{array}{l}\text { Qualitative } \\
\text { Description }\end{array}$ \\
\hline \multicolumn{4}{|l|}{ Affective Strategies } \\
\hline 1. I try to relax whenever I feel afraid of using English. & 3.28 & 0.97 & $\begin{array}{l}\text { Somewhat } \\
\text { true of me }\end{array}$ \\
\hline 2. I encourage myself to speak English even if I am afraid of making a mistake. & 3.62 & 1.1 & $\begin{array}{l}\text { Somewhat } \\
\text { true of me }\end{array}$ \\
\hline 3. I give myself a reward or treat when I do well in English. & 2.63 & 1.18 & $\begin{array}{l}\text { Somewhat } \\
\text { true of me }\end{array}$ \\
\hline 4. I notice if I am tense or nervous when I am studying or using English. & 3.17 & 1.09 & $\begin{array}{l}\text { Somewhat } \\
\text { true of me }\end{array}$ \\
\hline 5. I write down my feelings in a language learning diary. & 2.09 & 1.22 & $\begin{array}{l}\text { Somewhat } \\
\text { true of me }\end{array}$ \\
\hline 6. I talk to someone else about how I feel when I am learning English. & 2.92 & 1.19 & $\begin{array}{l}\text { Somewhat } \\
\text { true of me }\end{array}$ \\
\hline Average & 2.95 & 1.13 & $\begin{array}{l}\text { Somewhat } \\
\text { true of me }\end{array}$ \\
\hline \multicolumn{4}{|l|}{ Social Strategies } \\
\hline $\begin{array}{l}\text { 1. If I do not understand something in English, I ask the other person to slow down or say } \\
\text { it again. }\end{array}$ & 3.58 & 1.08 & $\begin{array}{l}\text { Somewhat } \\
\text { true of me }\end{array}$ \\
\hline 2. I ask English speakers to correct me when I talk. & 3.2 & 1.2 & $\begin{array}{l}\text { Somewhat } \\
\text { true of me }\end{array}$ \\
\hline 3. I practice English with other students. & 3.82 & 1.08 & $\begin{array}{l}\text { Somewhat } \\
\text { true of me }\end{array}$ \\
\hline 4. I ask for help from English speakers. & 3.18 & 1.14 & $\begin{array}{l}\text { Somewhat } \\
\text { true of me }\end{array}$ \\
\hline 5. I ask questions in English. & 3.22 & 0.98 & $\begin{array}{l}\text { Somewhat } \\
\text { true of me }\end{array}$ \\
\hline 6. I try to learn about the culture of English speakers. & 2.96 & 1.07 & $\begin{array}{l}\text { Somewhat } \\
\text { true of me }\end{array}$ \\
\hline Average & 3.33 & 1.09 & $\begin{array}{l}\text { Somewhat } \\
\text { true of me }\end{array}$ \\
\hline
\end{tabular}

Table 4B. Mean, standard deviation and description of the respondents' ALLS and SLLS

\begin{tabular}{|c|c|c|c|}
\hline $\begin{array}{l}\text { BSCE } \\
\text { Language Learning Strategies }\end{array}$ & Mean & $\begin{array}{l}\text { Std. } \\
\text { Deviation }\end{array}$ & $\begin{array}{l}\text { Qualitative } \\
\text { Description }\end{array}$ \\
\hline \multicolumn{4}{|l|}{ Affective Strategies } \\
\hline 1. I try to relax whenever I feel afraid of using English. & 3.417 & 0.97 & High \\
\hline 2. I encourage myself to speak English even if I am making a mistake. & 3.52 & 0.97 & High \\
\hline 3. I give myself a reward or treat when I do well in English. & 2.58 & 0.97 & $\begin{array}{l}\text { Somewhat } \\
\text { true of me }\end{array}$ \\
\hline 4. I notice if I am tense or nervous when I am studying or using English. & 3.18 & 1.19 & $\begin{array}{l}\text { Somewhat } \\
\text { true of me }\end{array}$ \\
\hline 5. I write down my feelings in a language learning diary. & 2.17 & 1.07 & $\begin{array}{l}\text { Somewhat } \\
\text { true of me }\end{array}$ \\
\hline 6. I talk to someone else about how I feel when I am learning English. & 2.8 & 1.24 & $\begin{array}{l}\text { Somewhat } \\
\text { true of me }\end{array}$ \\
\hline Average & 2.94 & 1.07 & $\begin{array}{l}\text { Somewhat } \\
\text { true of me }\end{array}$ \\
\hline \multicolumn{4}{|l|}{$\underline{\text { Social Strategies }}$} \\
\hline $\begin{array}{l}\text { 1. If I do not understand something in English, I ask the other person to slow down } \\
\text { or say it again. }\end{array}$ & 3.56 & 1.1 & High \\
\hline 2. I ask English speakers to correct me when I talk. & 3.07 & 1.17 & $\begin{array}{l}\text { Somewhat } \\
\text { true of me }\end{array}$ \\
\hline 3. I practice English with other students. & 3.21 & 1.04 & $\begin{array}{l}\text { Somewhat } \\
\text { true of me }\end{array}$ \\
\hline 4. I ask for help from English speakers. & 3.09 & 1.07 & $\begin{array}{l}\text { Somewhat } \\
\text { true of me }\end{array}$ \\
\hline 5. I ask questions in English. & 3.14 & 0.95 & $\begin{array}{l}\text { Somewhat } \\
\text { true of me }\end{array}$ \\
\hline 6. I try to earn about the culture of English speakers. & 3.02 & 1.11 & $\begin{array}{l}\text { Somewhat } \\
\text { true of me }\end{array}$ \\
\hline Average & 3.18 & 1.07 & $\begin{array}{l}\text { Somewhat } \\
\text { true of me }\end{array}$ \\
\hline
\end{tabular}


Tables 4A and 4B indicate the mean, standard deviation and description of the respondents' affective and social language learning strategies.

4.3 What Is the English Proficiency Level of the Students when Grouped According to Degree Programs?

Table 5. English proficiency level of the respondents

\begin{tabular}{llll}
\hline Course & Mean & Std. Deviation & Proficiency Level \\
\hline BSABE & 71.7281 & 8.48558 & Moderate \\
BSCE & 70.1408 & 8.84267 & Moderate \\
TOTAL & $\mathbf{7 0 . 8 4 7 7}$ & $\mathbf{8 . 7 0 4 5 3}$ & Moderate \\
\hline
\end{tabular}

Table 5 presents the respondents' English Proficiency Level.

As shown in Table 5, the English proficiency level of BSABE has a moderate level (71.72) with sstandard deviation of 8.49. However, the proficiency level of BSCE was also moderate (70.14) and standard deviation of 8.84. The total mean and standard deviation for the respondents' English proficiency was 70.8477 and 8.70453 which fall under "moderate level" based on proficiency index range of 70.0-79.9.

4.4 What Relationship Exists Between Speaking Anxiety and the Selected Variables when Students Are Grouped According to Degree Programs?

Table 6A. Correlations between the respondents' English proficiency and speaking anxiety

\begin{tabular}{|c|c|c|c|}
\hline \multicolumn{2}{|l|}{ BSABE } & \multirow{2}{*}{$\begin{array}{l}\text { Proficiency } \\
1\end{array}$} & \multirow{2}{*}{$\begin{array}{l}\text { Anxiety } \\
-.158\end{array}$} \\
\hline Proficiency & Pearson Correlation & & \\
\hline \multirow{5}{*}{ Anxiety } & Sig. (2-tailed) & & .092 \\
\hline & $\mathrm{N}$ & 114 & 114 \\
\hline & Pearson Correlation & -.158 & 1 \\
\hline & Sig. (2-tailed) & 0.92 & \\
\hline & $\mathrm{N}$ & 114 & 114 \\
\hline
\end{tabular}

Note. ${ }^{* *}$ Correlation is significant at the 0.01 level (2-tailed).

Table 6B. Correlations between the respondents' English proficiency and speaking anxiety.

\begin{tabular}{llll}
\hline BSCE & & Proficiency & Anxiety \\
\hline Proficiency & Pearson Correlation & 1 & $-.243^{* *}$ \\
& Sig. (2-tailed) & & .004 \\
& $\mathrm{~N}$ & 142 & 142 \\
& Pearson Correlation & -.243 & 1 \\
& Sig. (2-tailed) & .004 & 142 \\
\hline
\end{tabular}

Note. ${ }^{* *}$ Correlation is significant at the 0.01 level (2-tailed).

It appeared in Tables 6A and 6B the relationship between English proficiency and speaking anxiety of the respondents.

It shows in Table 6A that BSABE's speaking anxiety level has a small negative correlation between their English proficiency with pearson-r computed .16 with $\mathrm{p}>.0005$. On the other hand, Table 6B presents BSCE's speaking anxiety has also a small negative correlation between their English proficiency with pearson-r computed .24 and $p>.0005$. The correlation between two variables are significant at 0.01 level (2-tailed). Therefore, the hypothesis that there is no significant relationship between English language proficiency and speaking anxiety is rejected. 
Table 7A. Correlations between speaking anxiety and affective language learning strategies

\begin{tabular}{llll}
\hline BSABE & & Speaking Anxiety & ALLS \\
\hline Anxiety & Pearson Correlation & 1 & $.383^{* *}$ \\
& Sig. (2- tailed) & & .000 \\
& $\mathrm{~N}$ & 114 & 114 \\
ALLS & Pearson Correlation & $.383^{* *}$ & 1 \\
& Sig. (2- tailed) & .000 & \\
& $\mathrm{~N}$ & 114 & 114 \\
\hline
\end{tabular}

Note. ${ }^{* *}$ Correlation is significant at the 0.01 level (2-tailed).

Table 7B. Correlations between speaking anxiety and affective language learning strategies

\begin{tabular}{llll}
\hline BSCE & & Speaking Anxiety & ALLS \\
\hline Anxiety & Pearson Correlation & 1 & $.245^{* *}$ \\
& Sig. (2- tailed) & & .003 \\
& N & 142 & 142 \\
ALLS & PearsonCorrelation & $.245^{* *}$ & 1 \\
& Sig. (2- tailed) & .003 & \\
& $\mathrm{~N}$ & 142 & 142 \\
\hline
\end{tabular}

Note. ${ }^{*}$ Correlation is significant at the 0.01 level (2-tailed).

Tables 7A and 7B display the correlations between speaking anxiety and affective language learning strategies of the respondents. The BSABE students' speaking anxiety level has a significant relationship in ALLS with pearson-r computed .38 and $\mathrm{p}>.0005$.

Table 8A. Correlations between speaking anxiety and social language learning strategies

\begin{tabular}{llll}
\hline BSABE & & Speaking Anxiety & SLLS \\
\hline Anxiety & Pearson Correlation & 1 & 0.49 \\
& Sig. (2- tailed) & & .602 \\
& N & 114 & 114 \\
SLLS & Pearson Correlation & 0.49 & 1 \\
& Sig. (2- tailed) & .602 & \\
& N & 114 & 114 \\
\hline
\end{tabular}

Table 8B. Correlations between speaking anxiety and social language learning strategies

\begin{tabular}{llll}
\hline BSCE & & Speaking Anxiety & SLLS \\
\hline Anxiety & Pearson Correlation & 1 & 0.76 \\
& Sig. (2- tailed) & & .369 \\
& N & 142 & 142 \\
SLLS & Pearson Correlation & 0.76 & 1 \\
& Sig. (2- tailed) & .369 & \\
& N & 142 & 142 \\
\hline
\end{tabular}

Tables $8 \mathrm{~A}$ and $8 \mathrm{~B}$ show the speaking anxiety's correlation with social language learning strategies of the respondents. Table $8 \mathrm{~A}$ reveals that BSABE's speaking anxiety level was positively correlated with their social language learning strategies $(\mathrm{r}=.05, \mathrm{n}=114, \mathrm{p}>.0005)$. It also indicates in Table $8 \mathrm{~B}$ a small positive correlation between speaking anxiety and social language learning strategies for the BSCE students. A significant relationship was found between the two variables $(r=.08, n=142, p>.0005)$. This leads us to the rejection of the hypothesis that there is no relationship between social language learning strategies and speaking anxiety.

\section{Discussion}

The findings indicate that ESL learners experience anxiety in communication, but this anxiety is moderate in all items. This simply implies that even if ESL learners' manifest anxiety, they do not want to miss classes. It only emphasizes the degree of importance students give to their English class.

Communication apprehension in language learning is described as the unwillingness of the learner to talk and the 
feeling of being shy in engaging in communication. This is so because of the uniqueness of language learning process (Horwitz et al., 1986, p. 128). To cite Aida's (2004), typical communicatively apprehensive person has the tendency to avoid and disengage himself from. The learners who are anxious usually entertain the thought of cutting classes in order to avoid anxiety situations which usually led them to be lagging behind. Oral communication skill involves two important concepts: listening and speaking, however, speaking is considered to be the most critical in inducing anxiety in the context of second language acquisition as disclosed by Maclntyre and Gardner (1991a). As Young (1990) opined, students were extremely anxious when they had to speak in a foreign language in front of their class. It is a truism that speaking in front of a class makes one so anxious. That is why students are reluctant to do so because it makes them feel uneasy and nervous whenever they participate in class discussion. Many researches subscribed to this idea, Jones (2004, p. 32), Koch and Terrell (1991), Price (1991), Young (1990), Young (1991), Tanveer (2007).

The scenario in the university is not much different. Students don't have the chance to practice their English language, except inside the class. The time they are exposed to the language is not enough to help them express themselves more freely and as a result have less common anxiety.

As shown in Table 3A, it was noted that all of the six strategies were "somewhat true" for the respondents as indicated in table using the computed mean. Similar study regarding diary keeping was found in Altunay's (2013) which was carried out with another group of distance EFL learners. The six strategies for the Agricultural and Biosystems Engineering students were generally "somewhat true" for them.

On the other hand, it was also reflected in Table 3B that item number 2 also obtained the highest mean score. Table 3B also reveals affective strategy statement number 6 "I talk to someone else about how I feel when I am learning English" gained the lowest mean score. Among the six ALLS, "I try to relax whenever I feel afraid of using English" and "I encourage myself to speak English even if Im afraid of making a mistake"are the only items which are usually true for the Civil Engineering students, yet the average for their ALLS is still "somewhat true" for them.

The findings conform to the study of Querol (2010) that the best way to learn the language is by means of using it every day. It is a good practice for learners to engage themselves in communication events in order to conquer their anxiety in speaking the English language. One must also conquer the feeling of being afraid of using the language. The same proposition is advocated by Oxford (1990) who has a strong belief that affective domain influences the success or failure of a learner in learning a language. These factors are culture, inhibition, anxiety, risk-taking and tolerance. They may hamper the process of learning a language. It is up to the students to control the occurrence of such factors as regards language learning.

However, as gleaned in Table 3A, the six social strategies for the Agricultural and Biosystems Engineering students were all "somewhat true" for them. The highest mean as reflected in table can be obtained in item number 3; "I practice English with other students".followed by the statement "If I do not understand something in English, I ask he other people to slow down or say it again". Additionally, the average respondents' SLLS were also "somewhat true" for them.

Moreover, usually true among the social strategies of Civil Engineering students is "If I do not understand something in English, I ask the other person to slow down or say it again" with a mean of 3.56. The average mean and standard deviation for Civil Engineering students.

The result implies that Agricultural and Biosystems Engineering and Civil Engineering students have a moderate English Proficiency Level. Furthermore, the need to be proficient in the use of English among non-native speakers according to Gibbons (2003) has become a global phenomenon. In contrary to the findings, AlFadly (2003) stated that Arab students remain unable to achieve the desired proficiency in English even after studying the language for many years. This was supported by the study of Chin et al. (2004) that standardized tests are usually given in English, and ESL students have consistently lower test scores than students whose native language is English.

The relationship between the respondents' speaking snxiety and English proficiency level was investigated using Pearson product-moment correlation coefficient. Preliminary analyses were performed to ensure no violation of the assumptions of normality, linearity and homoscedasticity. A similar view is presented by Jean-Mark Dewaele and Tsui Shan Ip (2013) mentioned that Communication Anxiety was negatively correlated with the students' performance in English.

The above findings are in consonance with the study of MacIntyre and Gardner (1991) whose findings revealed that anxiety could be a predictor of success in second language learning. Similar studies by Masgoret et al. (1997) 
discovered the strong correlation between anxiety and proficiency. This implies that learners with low anxiety tend to be successful in language learning. So, the understanding of language teachers on the factors affecting language learning is significant in fostering knowledge and encouraging students to engage in communicative events in school.

Liu and Jackson (2008), and Pichette's (2008) found out that being anxious in classroom is connected with language achievement.

On the contrary, Brown (2008) claimed that students with excellent performance in language are those that possessed low level of anxiety. This is strengthened by the findings of Koul, Roy, Kaewkuekool and Ploisawaschai (2009) who found out that academic achievement and language anxiety are strongly correlated.

The above stated results are in similar view with the study of Andrew Yau-Tse (2011) stated that "the use of affective teaching strategies will ultimately make students more confident". In line with this, affective strategies according to Altunay (2014) are used to decrease anxiety, increase self-encouragement and take one's emotional temperature. Therefore, it can be noted that LLS such as affective strategies improves better language learning. By lowering anxieties and controling emotions are some of the best helpful ways to obtain successful language learning.

There exists also a significant relationship between their speaking anxiety level and ALLS of the BSCE respondents with pearson-r computed .25 and $\mathrm{p}>.0005$. There was a medium positive correlation between the two variables for Agricultural and Biosystems Engineering and Civil Engineering students. Therefore, the null hypothesis which states that "there is no significant relationship between the affective language learning strategies and speaking anxiety is rejected. A similar statistical method was utilized by Philips (1992), Onwuegbuzie et al. (1999), Noormohammadi (2009) and Aida's (1994) studies to find out the relationship between language anxiety and the chosen factors course grades, oral exam grades, language learning strategies, etc.

Pearson product-moment correlation coefficient was utilized in the language strategies and preliminary analyses were performed. The above descriptive result was supported by Mohammadi stated that "research on the relationship between LLS and language learning anxiety have indicated that there is a meaningful relationship between different subsets of LLS and language anxiety". However, this finding contradicts by Noormohammadi (2009) in his study found a negative and significant correlation between all categories of LLS and language anxiety.

\section{Conclusion}

The study has implications for language teaching. ESL learners are advised to know their strengths and weaknesses in order to address their anxiety in classrooms. It is on this way that they will be able to venture on activities that would increase their self-confidence in the class like increasing their vocabulary. This scenario can help them boost their morale in participating during class discussions and other related communication activities in English classes and other disciplines that require their full participation in the class. Teachers likewise are potent agents of rekindling the awareness of students as regards anxiety in order to free them from this great disturbance in their studies.

The SLLS and ALLS are utilized by the students in order to enhance their language skills. Hence, these strategies should be integrated in language classes in order for the students to cope with the demands of various language learning tasks. If students are unable to conduct or use the said strategies, supporting them in the development of such would make them more competent in managing their knowledge of the language. It is a must that both SLLS and ALLS can be taught and enhance since there is a correlation between the two, similar to the claim of Querol (2010).

For language teaching professionals, it is suggested that the learning of ALLS and SLLS be implemented in the language classroom as this will make students cognizant of their learning of the language. Being aware of their own learning will make them aware and competent in monitoring their mastery of their language skills. As regards direction for research, further exploration of ALLS and SLLS should be conducted to have a broader list of the said strategies. Moreover, succeeding researchers should be contextualized in students in other fields such as business and economics, hospitality management, and other disciplines to see whether similar strategies are employed by the students. Also, if the study is done in another cultural context, further abstractions and stronger generalizations can be made in the field of language learning strategy research. Radwant (2010) concluded that LLS results may vary as a result of cultural variation. Lastly, utilizing a bigger sample size would be advantageous as it makes the claim more consistent. 


\section{References}

Aida, Y. (1994). Examination of Horwitz, Horwitz, and Cope's construct of foreign language anxiety: The case of students of Japanese. The Modern Language Journal, 78, 155-168. https://doi.org/10.1111/j.1540-4781.1994.tb02026.x

Andrew, Y.-H. T. (2011). To be Anxious or not to be Anxious-That is the question in Public Speaking. Centre of Modern Languages and Human Sciences, University Malaysia Pahang. Retrieved January 27, 2015, from http://umpir.ump.edu.my/2283/

Chamot, A. (2004). Issues in language learning strategy research and teaching. Electronic Journal of Foreign Language teaching, 1(1), 14-26.

Dr. Altunay. (2014). Language Learning Strategies used by distance leaners of English. TOJDE, 15(3). https://doi.org/10.17718/tojde.30083uar

Dr. Karekatti et al. (2012). A study of Language Learning Strategies Used by the Engineering Students. English for Specific World, 35. Retrieved January 25, 2015, from http://www.esp-world.info

Gardner, R. C., \& MacIntyre, P. D. (1992). Integrative motivation, induced anxiety, and language learning in a controlled environment. Studies in Second Language Acquisition, 14(2), 197-214.

Horwitz, E. K. (2001). Language anxiety and achievement. Annual Review of Applied Linguistics, 21, 112-126. https://doi.org/10.1017/S0267190501000071

Inthakanok, I. (2009-2011). Speaking anxiety of a group of Thai EFL university students: Its sources and coping strategies. Journal of Education Silapakorn University, 1-2, 82-101. https://doi.org/10.32890/mjli2016.13.1.4

Javid et al. (2013). Effects of Eglish Language Proficiency on the Choice of Language Learning Strategies by Saudi English-major Undergraduates. English Language Teaching, 6(1), 35. https://doi.org/10.5539/elt.v6n1p35

Jones, J. F. (2004). A Cultural Context for Language Anxiety. EA (English Australia) Journal, 21(2), 30-39.

Kavasoglu, M. (2009). Learning strategy use of pre-service teachers of English language at Mersin University. Procedia Social and Behavioral Sciences, 1, 993-997. https://doi.org/10.1016/j.sbspro.2009.01.177

Koch, A. S., \& Terrell, T. D. (1991). Affective Relations of Foreign Language Students to Natural Approach Activities and Teaching Techniques. In E. K. Horwitz, L. R. K. Young \& R. Oxford (Eds.), Understanding EFL learners' strategy use and strategy awareness, 10(1).

Liu, M. (2007). Anxiety in oral English classrooms: A case study in China. Indonesian Journal of English Language Teaching, 3(1), 119-137.

MacIntyre, P. D., \& Gardner, R. C. (1989). Anxiety and second-language learning: Toward a theoretical clarification. Language Learning, 39, 251-275. https://doi.org/10.1111/j.1467-1770.1989.tb00423.x

Mayer, R. (1998). Learning strategies: An overview. In Weinstein, C. E. Goetz \& P. Alexander (Eds), Learning and study strategies: Issues in assessment, instruction, and evaluation (pp. 11-22). New York: Academic Press. https://doi.org/10.1016/B978-0-12-742460-6.50008-6

McCroskey, J. C. (1977). Oral Communication Apprehension: A Summary of Recent Theory and Research. Human Communication Research, 4(1) 78-96. https://doi.org/10.1111/j.1468-2958.1977.tb00599.x

McCroskey, J. C., Gudykunst, W. B., \& Nishida, T. (1999). Communication Apprehension Among Japanese Students in Native and Second Language. West Virginia University, U.S.: Department of communication Studies.

Meihua L. (2007). Anxiety in Oral English Classroom: A Case Study in China. Indonesian Journal of English Language Teaching, 3(1), 119.

Michael, L. C. (1997). Language learning strategies: An overview for L2 teachers, Essays in languages and literatures, $8 . \quad$ Kwansei Gakuin Univertsity. Retrieved from http://caria.acad.umn.edu/sistrategies.htm101-27-15

Mohammadi, E. G. et al (nd). The Relationship between Foreign Language Anxiety and Language Learning Strategies among University Students. Theory and Practice in Language Studies, 3(4), 637-646. https://doi.org/10.4304/tpls.3.4.637-646 
Nunan, D. (1988). The learner-centered curriculum. Cambridge: Cambridge University Press. https://doi.org/10.1017/CBO9781139524506

Nunan, D. (1995). Closing the gap between learning and instruction. TESOL Quarterly, 29(1), 133-158. https://doi.org/10.2307/3587808

O’Malley, J., \& Chamot, A. (1990). Learning strategies in second language acquisition. Cambridge, England: Cambridge University Press. https://doi.org/10.1017/CBO9781139524490

Oxford, R. (1990). Language learning strategies: What every teacher should know. New York: Newbury House.

Oxford, R. (1992/1993). Language learning strategies in a nutshell: Update and ESL suggestions. TESOL Journal, 2(2), 18-22.

Park, G. P. (2010). Investigation into learning strategies used by effective and less effective EFL learners in Korea. Asian Social Science, 6(8), 3-13. https://doi.org/10.5539/ass.v6n8p3

Price, M. L. (1991). The Subjective Experience of Foreign Language Anxiety: Interview with Highly Anxious Students. In E. K. Horwitz, \& D. J. Young (Eds.), Language Anxiety: From Theory and Research to Classroom Implications (pp. 101-108). Englewood Cliffs, NJ: Prentice Hall.

Querol, B. M. (2010). College students' use of affective and social language learning strategies: a classroom-based research. Philippine ESL Journal, 5, 22-39.

Radwan, A. A. (2010). Effects of L2 proficiency and gender on choice of language learning strategies by university students majoring in English. Asian EFL Journal, 125-163.

Shu-chin, Y., \& Tun-Whei, C. (2009). The effect of MTI on L2 proficiency and learning strategies. The Asian EFL Journal Quarterly, 11(3), 9-28.

Tanveer, M. (2007). Investigation of the factors that cause language anxiety for ESL/EFL learners in learning speaking skills and the influence it casts on communication in the target language. Unpublished M.Ed. Dissertation, University of Glasgow

Tudor, I. (1996). Learner-centeredness as language education. Cambridge: Cambridge University Press.

Velasco, J. C., \& Lan, M. V. T. N. (2013). Affective and Social Language Learning Strategies of ESL Engineering Students. The International Journal of Language, Literature and Culture, 55-65.

Wan et al. (2010). ESL Students Communications Apprehension and their Choice of Communicative Activities. AJTHE, 2(1), 22-29.

Wang, T. J. (2010). Speaking Anxiety: More of a Function of Personality than Language Achievement. Chinese Journal of Applied Linguistics (Bimonthly), 33(5).

Wong, L. L., \& Nunan, D. (2011). The learning styles and strategies of effective language learners. System, 39, 144-163. https://doi.org/10.1016/j.system.2011.05.004

Young, D. J. (1990). An Investigation of Students' Perspectives on Anxiety and Speaking. Foreign Language Annals, 23, 539-553. https://doi.org/10.1111/j.1944-9720.1990.tb00424.x

Young, D. J. (1991). Creating a Low-Anxiety Classroom Environment: What Does Language Anxiety Research Suggest? The Modern Language Journal, 75(4), 426-439. https://doi.org/10.1111/j.1540-4781.1991.tb05378.x

Yusuke, K. (n.d.). A study on the relationship between Language Anxiety and Proficiency: In a case of Japanese Learners of English. Retrived from http://www.paaljapan.org/resources/proceedings/PAAL10/pdfs/kondo.pdf

\section{Copyrights}

Copyright for this article is retained by the author, with first publication rights granted to the journal.

This is an open-access article distributed under the terms and conditions of the Creative Commons Attribution license (http://creativecommons.org/licenses/by/4.0/). 